\title{
BIOLOGICAL STUDIES OF Nigma conducens (Cambridge,1876) (Araneae: Dictynidae)
}

\author{
Elsayed G. I. Hamada, E. A. Wahba and A.I. Amer \\ Plant Protection Institute, ARC, Dokki, Giza, Egypt
}

\begin{abstract}
The spider, Nigma conducens (Cambridge, 1876) was locality recorded in El-Gharbia Governoraye, Egypt. It was collected from cotton plants cultivated in El-Gemmeiza Agricultural Research Station, El- Gharbia Governorate. The biology of the spider, Nigma conducens (Cambridge,1876) was studied under laboratory conditions of $28{ }^{\circ} \mathrm{C}$ and $60-65 \% \mathrm{RH}$ on nymphs and adult stages of the cotton jassid, Empoasca lybica (De Berg.). Males pass through five spiderling instars, while females pass through six spiderling instars before reaching adult stage. The mean of female preoviposition, oviposition and post-oviposition periods were 15.8, 19.5 and 44.5 days, respectively. The female laid 3-6 egg sacs. The mean number of egg/sac was 12-19 eggs. The incubation period of eggs was 11.7 days. The life cycle of this spider was 59.2 days for male and 62.6 for female. Adult longevity, life span, fecundity of female and food consumption were also studied.
\end{abstract}

Key words: Spider - Dictynidae - Nigma conducens - life span

\section{INTRODUCTION}

species of spider belonging to the family Dictynidae which was registered as a new species in upper Egypt, Elephantine, Philoe island (Aswan), Wadi-Halfa by Cambridge ,1876. This species was listed in El-Hennawy (2006) and World Spider Catalog (2015) as one genus and one species around the world, where no literature was reported at Africa. The purpose of this article to biological studies of this spider under laboratory conditions at El-Gharbia Governorate, Egypt.

\section{MATERIAL AND METHODS \\ Collection and rearing of the Spider:}

Adult female of Nigma conducens was collected by hands from cotton plants using camel hair brush, and placed in a glass tube (1 $\mathrm{cm} \times 9 \mathrm{~cm}$ depth) covered with plastic cover and transferred to the laboratory. Individuals were reared under laboratory conditions of 28 ${ }^{\circ} \mathrm{C}$ and $60-65 \% \mathrm{RH}$. After egg sacs were laid by females, every newly hatched spiderling was transferred to a separate tube, where it was daily supplied with adult and nymphs stages of Jassid as food adult 
female or spiderlings until the complete of the life span. All biological aspects of the spider were determined according to Abo-Taka et al. (2003), Aiad et al. (2013), Abdel-Sattar et al.(2015) and Mohafez (2015).

\section{Collection and rearing of Jassids as prey :}

Jassid nymphs and adult stages were collected by hairy brush from the lower surface of cotton leaves and were put inside small containers supplied with some green leaves to remain alive and transported to the laboratory to introduce it as foods to spiders, stages. The obtained data were analyzed by counting the average $( \pm)$ standard error according to CoStat software program (Version 6.400).

\section{Biological studies:}

\section{RESULTS AND DISCUSSION}

\section{a- Development stages :}

Data presented in Table (1) show the duration periods of different stages of the spider, Nigma conducens. Results indicated that the incubation period ranged between $7-12$ days with mean \pm SE as $11.7 \pm 0.2$. Females have six spiderlings each has duration ranged between 6-12 days with total of $47-64$ days and mean $50.9 \pm 3.6$ days. While the males have five spiderlings each has duration ranged between $6-13$ days with total of 25-52 days and mean $47.2 \pm 1.2$ days (Foelix, 1996).

Table (1): Duration of different stages of Nigma conducens feeding on different stages of Jassid, Empoasca lybica

\begin{tabular}{|l|c|c|c|c|}
\hline \multirow{2}{*}{$\begin{array}{c}\text { Developmental } \\
\text { Stages }\end{array}$} & \multicolumn{3}{|c|}{ Female } & \multicolumn{2}{c|}{ Male } \\
\cline { 2 - 5 } & Range & Mean \pm SE & Range & Mean \pm SE \\
\cline { 2 - 5 } & \multicolumn{4}{|c|}{ Duration in days } \\
\hline Incubation period & $7-12$ & $11.7 \pm 0.2$ & $7-12$ & $11.7 \pm 0.2$ \\
\hline $1^{\text {st }}$ spiderling & $8-11$ & $10 \pm 0.3$ & $7-10$ & $9.6 \pm 0.4$ \\
\hline $2^{\text {nd }}$ spiderling & $9-10$ & $6.1 \pm 0.9$ & $6-8$ & $7.5 \pm 0.2$ \\
\hline $3^{\text {rd }}$ spiderling & $9-10$ & $6.5 \pm 1.0$ & $9-12$ & $10.7 \pm 0.4$ \\
\hline $4^{\text {th }}$ spiderling & $7-12$ & $9.3 \pm 1.3$ & $7-13$ & $12.7 \pm 0.4$ \\
\hline $5^{\text {th }}$ spiderling & $6-10$ & $9.8 \pm 0.1$ & - & - \\
\hline $6^{\text {th }}$ spiderling & $8-11$ & $9.2 \pm 0.2$ & $25-52$ & $47.5 \pm 1.2$ \\
\hline Total spiderlings & $47-64$ & $50.9 \pm 3.6$ & $32-64$ & $59.2 \pm 1.2$ \\
\hline Life cycle & $54-76$ & $62.6 \pm 3.3$ & $26-48$ & $36.2 \pm 3.4$ \\
\hline Longevity & $27-53$ & $47.3 \pm 3.4$ & $58-112$ & $95.4 \pm 4.2$ \\
\hline Life span & $81-129$ & $109.9 \pm 7.0$ & \\
\hline
\end{tabular}

The life cycle of female lasted between 54-76 days with mean \pm SE $62.6 \pm 3.3$, On the other hand, 32-64 days in males with mean \pm SE $59.2 \pm 1.2$ days .

As for longevity it was $27-53$ at females with mean \pm SE $47.3 \pm$ 3.4 days, while it lasted $26-48$ days in males with mean \pm SE $36.2 \pm$ 3.4 days. The total life span was lasted for 81-129 days at females with mean \pm SE $109.9 \pm 7.0$ days, while it lasted 58-112 days for males with mean \pm SE $95.4 \pm 4.2$ days . 


\section{b- Fecundity of females:}

Data presented in Table (2) show the duration periods of the females of the studied spider. Results indicated that the pre-oviposition period ranged between $12-17$ days with mean \pm SE $15.8 \pm 1.3$ days, the Oviposition period 15-24 days with mean \pm SE $19.5 \pm 1.2$ days, and the Post-oviposition lasted $35-57$ days with mean \pm SE $44.5 \pm 2.3$ days.

As for the laid egg sacs, results in the same table indicated that the number of eggs / egg sac was ranged between 12-19 with mean \pm SE $17.6 \pm 2.5$, and each female laid 3-6 egg sacs with mean \pm SE $3.8 \pm 1.9$ sacs.

Table (2): Fecundity of Nigma conducens female feeding on different stages of Jassid, Empoasca lybica

\begin{tabular}{|l|c|c|}
\hline Developmental period of female & $\begin{array}{c}\text { Range } \\
\text { (days) }\end{array}$ & $\begin{array}{c}\text { Mean } \pm \text { SE } \\
\text { (days) }\end{array}$ \\
\hline Pre-oviposition & $12-17$ & $15.8 \pm 1.3$ \\
\hline Oviposition & $15-24$ & $19.5 \pm 1.2$ \\
\hline Post-oviposition & $35-57$ & $44.5 \pm 2.3$ \\
\hline The laid eggs & Range & Mean \pm SE \\
\hline Number of eggs / egg sac & $12-19$ & $17.6 \pm 2.5$ \\
\hline Number of egg sacs / female & $3-6$ & $3.8 \pm 1.9$ \\
\hline
\end{tabular}

c- Consumption of Nigma conducens fed on Jassid stages , Empoasca lybica:

Data presented in Table (3) show the consumption rates of the developmental stages of Nigma conducens males and females fed on Jassid stages, Empoasca lybica. The obtained data (Table 3) revealed that the consumption rate was increased by increasing the age of spiderlings at both males and females. Spiderlings of male consumed a total of 117-180 jassid stages with mean \pm SE $146.3 \pm$ 11.0 Jassid, while spiderlings of female consumed a total of 131-191 Jassid stages with mean \pm SE $158 \pm 7.6$ Jassid.

\section{d- Feeding behavior:}

The spider rushed out of its nest and grasped a leg of the prey with its chelicerae. Immediately, the spider released the prey and returned to its nest the spider initially grasped a leg or antenna of the prey. Of the spiders already feeding when found, some were feeding on the head, thorax, or abdomen of the prey, and it was noted that the spiders sometimes initially grasped the prey by its head or body rather than by an appendage (Jackson,1979). 
5 Elsayed. G. I. Hamada et al.,

Table (3): Consumption of the developmental stages of Nigma conducens males feeding on Jassid, Empoasca lybica

\begin{tabular}{|l|c|c|c|c|}
\hline \multirow{2}{*}{ Developmental stages } & \multicolumn{2}{|c|}{ Daily rate } & \multicolumn{2}{c|}{ Total } \\
\cline { 2 - 5 } & Range & Mean \pm SE & Range & Mean \pm SE \\
\cline { 2 - 5 } & \multicolumn{4}{|c|}{ mean no of jassid stages } \\
\hline \multicolumn{5}{|c|}{ Males } \\
\hline $1^{\text {st }}$ spiderling & $2-4$ & $2.2 \pm 0.4$ & $12-18$ & $15.1 \pm 1.1$ \\
\hline $2^{\text {nd }}$ spiderling & $3-5$ & $3.1 \pm 0.3$ & $17-22$ & $19.3 \pm 1.4$ \\
\hline $3^{\text {rd }}$ spiderling & $2-6$ & $3.5 \pm 1.4$ & $15-29$ & $21.1 \pm 2.6$ \\
\hline $4^{\text {th }}$ spiderling & $4-9$ & $6.3 \pm 2.6$ & $23-44$ & $37.6 \pm 4.3$ \\
\hline $5^{\text {th }}$ spiderling & $6-10$ & $8.1 \pm 2.1$ & $50-67$ & $53.2 \pm 1.6$ \\
\hline Total consumed & $17-34$ & $23.2 \pm 2.8$ & $117-180$ & $146.3 \pm 11.0$ \\
\hline \multicolumn{1}{|c|}{ Male longevity } & $6-22$ & $19.4 \pm 4.6$ & $150-227$ & $178.3 \pm 35.4$ \\
\hline \multicolumn{4}{|c|}{ Females } \\
\hline $1^{\text {st }}$ spiderling & $2-4$ & $3.2 \pm 2.2$ & $15-19$ & $16.5 \pm 1.3$ \\
\hline $2^{\text {nd }}$ spiderling & $2-5$ & $3.4 \pm 2.6$ & $16-25$ & $18.7 \pm 1.1$ \\
\hline $3^{\text {rd }}$ spiderling & $3-7$ & $4.6 \pm 3.1$ & $18-36$ & $25.2 \pm 2.4$ \\
\hline $4^{\text {th }}$ spiderling & $5-7$ & $4.3 \pm 2.3$ & $27-47$ & $36.3 \pm 2.1$ \\
\hline $5^{\text {th }}$ spiderling & $6-12$ & $7.1 \pm 2.4$ & $55-78$ & $63.1 \pm 3.2$ \\
\hline $6^{\text {th }}$ spiderling & $11-16$ & $8.3 \pm 3.2$ & $49-66$ & $58.6 \pm 2.3$ \\
\hline Total consumed & $29-51$ & $30.9 \pm 16.8$ & $131-191$ & $158 \pm 7.6$ \\
\hline Pre-oviposition & $7-11$ & $8.2 \pm 2.5$ & $103-135$ & $119.2 \pm 8.7$ \\
\hline Oviposition & $6-9$ & $9.3 \pm 3.3$ & $88-114$ & $107.5 \pm 7.6$ \\
\hline Post-oviposition & $20-28$ & $11.2 \pm 4.1$ & $35-103$ & $86.5 \pm 14.3$ \\
\hline Female longevity & $33-48$ & $28.7 \pm 9.9$ & $226-352$ & $313.2 \pm 29.7$ \\
\hline
\end{tabular}

\section{e- Description of adult male and female and sex ratio:}

The body length excluding legs is about 2 to $3.5 \mathrm{~mm}$, the females being slightly larger than the males (Figs. 1 - 2). The carapace is dark brown. The head is covered with five rows of white hairs. The abdomen has a pattern of white hairs with a gap in the cardiac region and at the rear. The legs are brownish yellow. Nigma conducens builds webs in the dried heads of plants and on gorse and heather.

Fig (1) Male 
From rearing Nigma conducens for one generation, sex ratio was recorded, where the male : female ratio was 1:1.2 .

\section{REFERENCES}

Abdel-Sattar M. M. ; M. A. Mohafez; M. A. Eldanasory and A. A. Elgendy(2015) Notes on the biology of Latrodectus tredecimguttatus (Rossi, 1790) (Araneae: Therididae).Serket vol. 14(4): 189-195.

Abo-Taka. S.M. ; A.M. Hussein; A. ; A.A.Osman ; G.I. Zohdi and E. G.I. Hamada (2003). Studies on some biological aspects of Erigone dentipalpis (Wider, 1834) (Arachnida : Araneida : Linyphiidae), Serket Vol. 8(4):142-146.

Aiad, K.A. and A. M. Halawa (2013). Preliminary trial for rearing the spider, Achaeranea lunata as a biocontrol agent of Spodoptra littoralis (Boisd.) Egypt. J. Agric. Res., 91 (4), 1415-1421.

Cambridge, O. P. (1876) Catalogue of a collection of spiders made in Egypt, with descriptions of new species and characters of a new genus., Proc. zool. Soc. Lond. 1876: 541-630.

CoStat version 6.400 Copyright (C) 1998-2008 Cohort Software. 798 Lighthouse Ave. PMB 320, Monterey, CA, 93940, USA.

El-Hennawy, H. (2006). A list of Egyptian spiders. Serket vol. 10(2): 6576.

Foelix, R. F. (1996). Biology of spiders. Second Edition. Oxford University Press \& George Thieme Verleg, New York, Oxford 330 pp.

Jackson, R. R. (1979). Comparative studies of Dictyna and Mallos (Araneae, Dictynidae). II. The relationship between courtship, mating, aggression and cannibalism in species with differing types of social organization. Rev., Arachnol., 2(3):103-132.

Mohafez, M.A.M. (2015). Biological aspects of the true spider Latrodectus geometricus Koch, 1841 (Araneae : Theridiidae) feeding on different prey under laboratory conditions. J. Plant Prot. and Path., Mansoura Univ., 6(7): 1123-1131.

World Spider Catalog(2015). World Spider Catalog. Natural History Museum Bern, online at http://wsc.nmbe.ch, version 16.5 , accessed on $\{25$ October 2015\}. 
7 Elsayed. G. I. Hamada et al.,

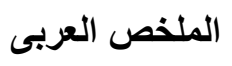

Nigma conducens (Cambridge,1876) دراسات بيولوجية للعنكبوت

التابع لعائلة Dictynidae

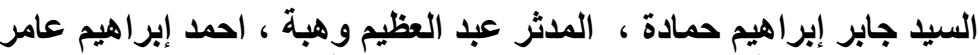

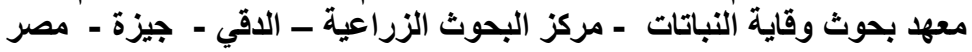

المفترس العنكبوتى Nigma conducens سجل في محافظة الغربية وتم جمعاه من

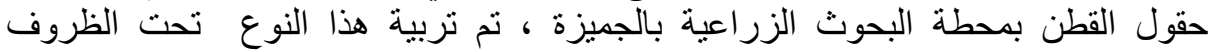

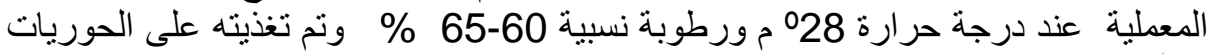
Empoasca lybica (De والأطوار الكاملة لجاسيد القطن حرن

مرت الذكور ب 5 أعمار غبر كاملة بينما مرت الإناث ب 6 أعمار غير كاملة قبل

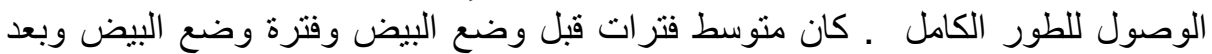

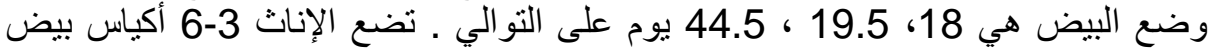

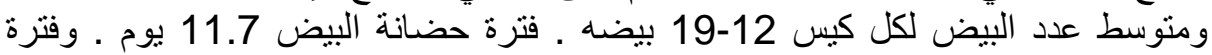
حياة العنكبوت 59.2 يوم للذكور و 62.6 يوم للإناث ، كما ت تم دراسة معدل الاستهلاك

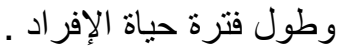

